\title{
Does Embankment Improve Quality of a River? A Case Study in To Lich River Inner City Hanoi, with Special Reference to Heavy Metals
}

\author{
Nguyen Thi Thuong*, Minoru Yoneda, Yasuto Matsui \\ Lab of Environmental Risk Analysis, Department of Environmental Engineering, Graduate School of Engineering, Kyoto University, \\ Kyoto, Japan. \\ Email: *ngthuong.ntt@gmail.com
}

Received January $31^{\text {st }}, 2013$; revised March $5^{\text {th }}, 2013$; accepted April $7^{\text {th }}, 2013$

Copyright (C) 2013 Nguyen Thi Thuong et al. This is an open access article distributed under the Creative Commons Attribution License, which permits unrestricted use, distribution, and reproduction in any medium, provided the original work is properly cited.

\begin{abstract}
To Lich River (TLR) system receives wastewaters from a population of nearly two million people and 100 manufactories of five industrial zones in inner city Hanoi, Vietnam. To improve quality of TLR, the embankment was carried out in 1998 and finished in 2002, resulted in width of $20-45 \mathrm{~m}$, depth of $2-4 \mathrm{~m}$, and maximum water flow capacity of 30 $\mathrm{m}^{3} / \mathrm{s}$. Water and sediment quality indices based on heavy metal concentrations were used to evaluate current river environment compared to that of pre-embankment. Mass balance model was employed to estimate total metal loads for specific river reaches, which corresponds to various types of wastewater discharged along the river. The results indicated that currently there is about $284,000 \mathrm{~m}^{3}$ sediment accumulated in TLR bed, which is under high contamination of $\mathrm{Cr}, \mathrm{Mn}, \mathrm{Fe}, \mathrm{Ni} \mathrm{Cu}, \mathrm{Zn}, \mathrm{As}, \mathrm{Cd}$, and $\mathrm{Pb}$ with a total of 7347 tons of all concerned metals. Domestic-discharged river reaches received much lower metal loads, roughly $8 \%-28 \%$ compared to river reaches of both domestic and industrial inputs. Total load of all nine concerned metals at the end of TLR is $161.7 \mathrm{~kg} / \mathrm{day}$, which is finally discharged to Nhue River at South Hanoi. Water quality was improved much right after finishing embankment, then it gradually deteriorated. Meanwhile, sediment quality became even much worse after embankment. Relative river quality index as equal weight for both water and sediment quality indices indicated that quality of TLR was not much improved after the embankment. It even became worse due to the urbanization in recent years.
\end{abstract}

Keywords: Industrial Discharge; Mass Balance; Metal Load; River Quality Index; Sediment Accumulation

\section{Introduction}

The economic, social, and environmental importance of water resource cannot be overstated. Water is a vital resource for healthy living conditions and sound ecosystems. Among the relevant issues that can be analyzed, water quality is quite significant [1]. Water body of polluted rivers, especially in densely populated cities, is usually blamed as a critical source of waterborne diseases and others. It is estimated that approximately onequarter of the global disease burden and more than onethird of the burden among children are due to modifiable environmental factors [2-4]. Materials, which are widely used in industries for their physical qualities, have proved carcinogenic, mutagenic and/or teratogenic in human $[5,6]$. Those materials are much responsible for

${ }^{*}$ Corresponding author. reduce of environmental quality, ecosystem degradation etc. Residual of those materials from industries, if managed improperly, is finally discharged to environment especially water bodies and accumulated in sediment.

Water bodies in a city are usually serving as discharging wastewaters. The health of a river is much depending on quality of discharged waters to its body. In being urbanized cities of developing countries, wastewater treatment is not much taken care leading to over pollution of water bodies. Pollution is facilitated in several respects in urban basins. First, un- and/or partially treated wastewater from both industry and municipality is discharged directly. Second, construction generates a number of pollutants that easily adsorb or dissolve in runoff. Third, high background pollution loads often accumulate in urban areas between rainy events, mostly from structural deterioration and improper disposals of solid waste of 
industry and municipality, and others. Many of those pollutants easily adsorb to particles suspended in runoff from construction sites as well [7]. The pollution loads often adversely affect water and sediment quality, and biological communities $[8,9]$.

Sedimentation is a natural process and represents a fundamental part of ecosystem functioning that is essential to the health of rivers and water bodies [10]. Many human activities such as manufacturing, construction, transportation as a manner of moving dirty, dramatically increase the rate of erosion, resulting in larger than normal sediment deposits in inner city rivers with various organic and heavy metal contaminants. Sediment loads from construction can be 10 - 20 times greater than cultivated lands [11], and its delivery ratios of $0.5-1.0$ are often reported for urban basins $[12,13]$. Those sediment loads often exceed the natural assimilative and equilibrating capacities of the receiving water systems. The contaminants of most concern are metals, polyaromatic hydrocarbons, polychlorinated biphenyls, and mineral oil. Therefore, disposal of polluted dredged sediments on land may lead to certain risks. Dredging is necessary to increase water flow rate, but also for remediation, whereas the risk for the environment and health might be high. Meanwhile, dredging of contaminated sediments faces problem of treatment and disposal of these contaminated sediments [14]. Currently, contaminated dredged sediments are often not valorisable due to their high content in contaminants and their consequent hazardous properties. Organics can be destroyed in place, whereas metals are immutable and relatively immobile. In addition, it is generally admitted that treatment and reuse of heavily contaminated dredged sediments is not a costeffective alternative to confined disposal.

This study aims at 1) evaluating contamination level of sediment and water, and quality of To Lich River (TLR) after 9 years embankment; 2) estimating total load of total organic carbon and heavy metals entered and accumulated in sediment in specific river reaches corresponding to its wastewater sources; and 3) estimating daily discharge of total organic carbon and heavy metals at the end of TLR.

\section{Materials and Methods}

\subsection{Study Site}

There are four main rivers forming To Lich River (TLR) system, which receives wastewaters from inner city of Hanoi and covers a basin area of $77.5 \mathrm{~km}^{2}$ [15]. To Lich is the biggest river receiving wastewaters from western part of Hanoi, while Kim Nguu, Set and Lu are three smaller ones receiving wastewaters from eastern part before discharging to TLR in downstream (Figure 1).
TLR originates from West Lake in North Hanoi, receiving mainly domestic wastewater in upstream and mix of domestic and industrial wastewater in downstream before joining Nhue River in South Hanoi through Thanh Liet Dam (Figure 1). The construction of embankment was completed in 2002, covering most of river reaches. The un-embanked upstream reach, which has a narrow width of $1-4 \mathrm{~m}$, is subjected to convert into a closed sewer. Currently, the embanked river reaches have a width of 20 - $45 \mathrm{~m}$ and depth of $2-4 \mathrm{~m}$, and a maximum flow capacity of $30 \mathrm{~m}^{3} / \mathrm{s}$. There are 239 point sources, including both pipe and box culverts along TLR [15]. Non-point sources are also available, such as illegal dumping practices and urban storm water runoff. In dry season, water released from West Lake is limited because of low water level. The input flow then is mainly wastewaters from households and industry with high contaminants [16].

There are five industrial zones located in TLR system basin, in which no suitable wastewater treatment systems are available [15]. Thuong Dinh industrial zone consists of 30 manufacturing plants, which have been directly discharging un- and/or partially treated wastewater to downstream reach of TLR. Those plants include: fourteen of mechanical industry, four of textile industry, three of leather industry, two of chemical industry (rubber and soap), two of ceramic industry, one of tobacco industry, one of paper industry, and three others. Other

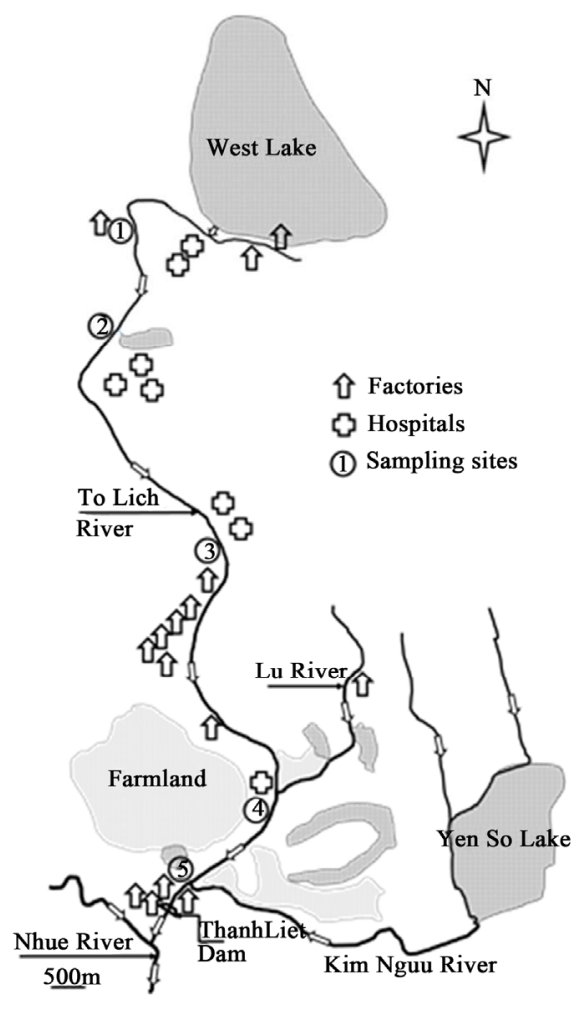

Figure 1. Map of study area showing sampling sites. 
four industrial zones, including 69 plants of all types of industries, discharge wastewaters to $\mathrm{Lu}$, Set, and Kim Nguu rivers, before entering TLR in downstream (Figure 1).

Thanh Liet Dam was built at $0.5 \mathrm{~km}$ from downstream to control water flow direction of TLR (Figure 1). The dam is closed when water level of TLR is lower than that of Nhue River and/or water of TLR is too polluted, which may affect the agricultural production at downstream of Nhue River. In such case, water runs to Yen So Lake through downstream reach of Kim Nguu River and then it is pumped to Red river.

\subsection{Sample Collection}

Surface water and sediment of $0-30,30-60,60$ - 90, and $90-120 \mathrm{~cm}$ depths were collected at five sites along the river (Figure 1). The first and second sampling sites were located in embanked river reach, receiving most domestic and hospital wastewater. The third sampling site was located right before discharge of Thuong Dinh industrial zone. The fourth and fifth sampling sites were located in un-embanked river reach, after confluence with Lu and Kim Nguu rivers, respectively. All samples were collected in dry season in March 4-5, 2011 (no rainy days).

Water samples were collected in pre-cleaned polypropylene bottles and preserved at $4^{\circ} \mathrm{C}$ in refrigerator until analysis. For heavy metal determination, the water samples were acidified with conc. $\mathrm{HNO}_{3}$ to $\mathrm{pH}<2$. The $\mathrm{pH}$ of water was measured in-situ using a portable $\mathrm{pH}$ meter. Meanwhile, sediment samples were taken from river bed using a self-made sediment sampler and placed into polyethylene bottles.

\subsection{Chemical Analysis}

Total organic carbon (TOC) contents in water and sediment were analyzed using a TOC analyzer (TOC-5000A, Shimadzu). For heavy metal analysis, sediment samples were air-dried at room temperature and passed through 1 $\mathrm{mm}$ stainless steel sieve to remove big particles. Then the samples were heated in an oven at $60^{\circ} \mathrm{C}$ until constant weight, powdered and homogenized. For microwaveassisted acid digestion procedure, roughly $50 \mathrm{mg}$ dry homogenized sediment was weighed into a vessel and successively digested with $10 \mathrm{~mL}$ of conc. $\mathrm{HNO}_{3}$ in a microwave digestion system [17]. After cooling, the digest was transferred into a plastic volumetric flask and adjusted to $50 \mathrm{~mL}$ volume with Mili-Q water. The sample was finally filtered through a membrane filter $(0.45$ $\mu \mathrm{m}$ pore size). Concentrations of heavy metals $(\mathrm{Cr}, \mathrm{Mn}$, $\mathrm{Fe}, \mathrm{Ni}, \mathrm{Cu}, \mathrm{Zn}, \mathrm{As}, \mathrm{Cd}$, and $\mathrm{Pb}$ ) in water and acid-digested sediment samples were determined using an in- ductively coupled plasma-mass spectrometry (ICP-MS).

Standard operating procedures, calibration with standards, and analysis of reagent blanks, and analysis of replicates were used to guarantee the quality of analytical data. Analysis for all samples was carried out in triplicate to get the mean as final data.

\subsection{General Characteristics of River}

Water flow rate $\left(Q ; \mathrm{m}^{3} / \mathrm{s}\right)$ at each sampling site was calculated as $Q=V \times A_{w}$, where $V$ is water velocity $(\mathrm{m} / \mathrm{s})$ and $A_{w}$ is cross-section of water body $\left(\mathrm{m}^{2}\right) . V$ was measured using FP101-FP201 Global Flow Probe. At each sampling site, three positions across the river (one in the center, one in each site with distance of $3 \mathrm{~m}$ from river banks) were measured for $V$ to get average value. Tape was used to measure width of water surface across river, while height stick was used for water and sediment depths (Figure 2). The sediment depth at each sampling site was just the depth of deepest sediment layer collected (Table 1). Slope of river bank was measured at each sampling site in degree to identify cross-sectional area of water and sediment bodies (Figure 2).

Area of water cross-section $\left(A_{w}\right.$ in $\left.\mathrm{m}^{2}\right)$ at each sampling site was calculated as following equation:

$$
\begin{aligned}
A_{w} & =((W-2 W D \times \tan (S))+W) \times W D / 2 \\
& =(2 W-2 W D \times \tan (S)) \times W D / 2 \\
& =(W-W D \times \tan (S)) \times W D \\
& =W \times W D-W D^{2} \times \tan (S)
\end{aligned}
$$

where, $W$ is width of water surface in meter, $W D$ is water depth in meter, $\mathrm{S}$ is slope of river bank in degree.

Area of sediment cross-section $\left(A_{s}\right.$ in $\left.\mathrm{m}^{2}\right)$ at each sampling site was calculated following Equation (2).

$$
\begin{aligned}
A_{s}= & \{((W-2 W D \times \tan (S))-2 S D \times \tan (S)) \\
& +(W-2 W D \times \tan (S))\} \times S D / 2 \\
= & \{W-2 W D \times \tan (S)-S D \times \tan (S)\} \times S D \\
= & \{W-\tan (S) \times(2 W D+S D)\} \times S D \\
= & S D \times W-\tan (S) \times\left(2 W D \times S D+S D^{2}\right)
\end{aligned}
$$

where $S D$ is sediment depth in meter.

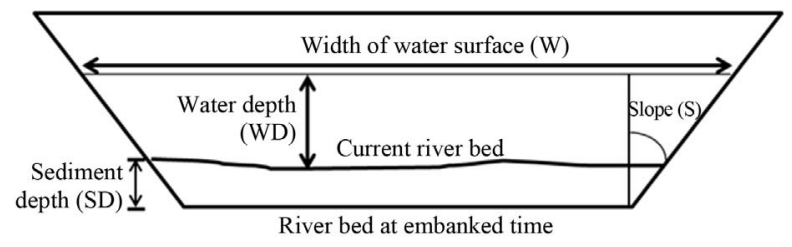

Figure 2. Vertical cross section of To Lich River. 
Table 1. General characteristics of specific reaches of To Lich River.

\begin{tabular}{|c|c|c|c|c|c|}
\hline Sampling site & $\mathrm{S} 1$ & S2 & S3 & S4 & S5 \\
\hline Distance from upstream $(\mathrm{km})$ & 3.1 & 5.1 & 9.1 & 13.8 & 15.5 \\
\hline Water depth (m) & 0.75 & 0.84 & 0.98 & 1.05 & 1.34 \\
\hline Area of water cross section $\left(\mathrm{m}^{2}\right)$ & 11.91 & 14.50 & 23.83 & 30.25 & 50.97 \\
\hline Water velocity $(\mathrm{m} / \mathrm{s})$ & 0.015 & 0.039 & 0.049 & 0.117 & 0.131 \\
\hline Flow rate $\left(\mathrm{m}^{3} / \mathrm{s}\right)^{1}$ & 0.18 & 0.57 & 1.16 & 3.53 & 6.68 \\
\hline Total travel time in a specific reach (days) ${ }^{2}$ & & 0.85 & 1.05 & 0.66 & 0.18 \\
\hline Sediment depth (m) & 1.2 & 1.2 & 1.2 & 0.9 & 0.6 \\
\hline Area of sediment cross section $\left(\mathrm{m}^{2}\right)$ & 16.16 & 18.00 & 26.57 & 23.60 & 21.03 \\
\hline Mean sediment cross sectional area $\left(\mathrm{m}^{2}\right)$ for a specific reach ${ }^{3}$ & & 17.08 & 22.29 & 25.08 & 22.31 \\
\hline Total sediment volume in a specific reach $\left(\mathrm{m}^{3}\right)^{4}$ & & 34,161 & 89,139 & 117,888 & 42,395 \\
\hline Average sediment density in a specific reach $\left(\mathrm{kg} / \mathrm{m}^{3}\right)^{5}$ & & 1053 & 1195 & 1242 & 1357 \\
\hline $\begin{array}{l}\text { Estimated cost required for treating sediment } \\
\quad\left(\text { average } \operatorname{cost}^{6} \text { of } 36 \mathrm{USD} / \mathrm{m}^{3}\right)\end{array}$ & & $1,229,784$ & $3,209,020$ & $4,243,957$ & $1,526,227$ \\
\hline
\end{tabular}

${ }^{1}$ equals to water velocity multiplying area of water cross section; ${ }^{2}$ equals to ratio of length $(\mathrm{m})$ to mean of water velocity (m/s) at first and last points of a specific river reach; ${ }^{3}$ equals to mean of first and last sediment cross sectional area of a specific river reach; ${ }^{4}$ equals to length of river reach multiplying mean sediment cross section; ${ }^{5}$ testing dry weight of known volume of sediment; ${ }^{6}$ composite unit costs extrapolated from case studies in USA range from a low of approximately $36 \mathrm{USD} / \mathrm{m}^{3}$ to over $600 \mathrm{USD} / \mathrm{m}^{3}[18]$.

\subsection{Loading of Heavy Metals}

Chemical mass balance model was introduced by Dolan and Shaarawi [19] to estimate chemical load in a river reach following Equation (3).

$$
Q_{d} C_{d}-Q_{u} C_{u}=\sum_{i=1}^{n} L_{i}
$$

where, $Q_{d}$ and $Q_{u}$ are downstream and upstream flows, $C_{d}$ and $C_{u}$ are downstream and upstream concentrations, and $\sum_{i=1}^{n} L_{i}$ is sum of all individual loadings to river reach. In fact, river contaminants undergo significant volatilizetion and/or degradation, therefore to improve the accuracy Equation (3) was modified by Jha et al. [20] as

$$
Q_{d} C_{d}-Q_{u} C_{u} \mathrm{e}^{-k t}=\sum_{i=1}^{n} L_{i}
$$

where, $k$ is rate of attenuation/decay coefficient $\left(\right.$ day $\left.^{-1}\right), t$ is travel time (day). $Q_{d} C_{d}$ is total load in downstream and/or at the end of river reach.

\subsection{River Quality Index}

Water quality index has been widely used to evaluate the quality/pollution levels of rivers [21-24]. In this study, we extend this knowledge to evaluate both water and sediment quality as a base for river quality assessment. In order to evaluate the improvement of river, a water quality index (WQI) and a sediment quality index (SQI) were developed based on seven parameters modeled $(\mathrm{Cr}, \mathrm{Mn}$, $\mathrm{Ni}, \mathrm{Cu}, \mathrm{Zn}, \mathrm{As}$ and $\mathrm{Pb}$ for water, and $\mathrm{Cr}, \mathrm{Ni}, \mathrm{Cu}, \mathrm{Zn}$ and
$\mathrm{Pb}$ for sediment).

The WQI and SQI were derived as the following manners:

$$
\begin{aligned}
\text { Index }_{\text {water }_{\text {metal }}} & =\frac{\text { Concentration in water }}{\text { metal }_{i \text { in yar A }}} \\
\text { Concentration in water } & \text { Wetal } \text { in }_{\text {in yar } B} \\
& =\left(\sum_{i=1}^{7} \text { Index }_{\text {water }_{\text {metal }}}\right) / 7
\end{aligned}
$$

where, Index water $_{\text {metal }}$ is quality index of metal $i$ in water, Concentration in water metal $_{\text {in year } A}$ is concentration in water of metal $i$ in year $A$, and Concentration in water $_{\text {metal }_{i \text { in year } B}}$ is concentration in water of metal $i$ in year $B(A>B)$.

$$
\begin{aligned}
\text { Index }_{\text {sediment }_{\text {metal }}} & =\frac{\text { Concentration in sediment }}{\text { metal }_{\text {in year } A}} \\
\text { Concentration in sediment } & \text { } \text { metal }_{i \text { in year } B}
\end{aligned}
$$

where, Index sediment $_{\text {metal }}$ is quality index of metal $i$ in sediment, Concentration in sediment metal $_{i \text { in year } A}$ and Concentration in sediment metal $_{\text {in year } B}$ are concentrations in sediment of metal $i$ in year $A$ and $B$, respectively $(A>B)$.

Subsequently, a simple relative river quality index (RQI) was derived giving equal weight for both WQI and SQI: 


$$
\mathrm{RQI}=(\mathrm{WQI}+\mathrm{SQI}) / 2
$$

where, WQI, SQI, and/or RQI equals 1 there is no improvement for water, sediment and/or river, while it is improved if the values are $<1$, and becomes worse if the values are $>1$.

\section{Results}

\subsection{General Characteristics of To Lich River}

The water velocity gradually increases from up to downstream as $0.015 \mathrm{~m} / \mathrm{s}$ at $\mathrm{S} 1$ to 0.039 at $\mathrm{S} 2,0.049$ at $\mathrm{S} 3$, 0.117 at $\mathrm{S} 4$, and $0.131 \mathrm{~m} / \mathrm{s}$ at $\mathrm{S} 5$ before discharging to Nhue River (Table 1). Corresponding to water velocity is water flow rate, which also increases toward downstream as result of various wastewater inputs along TLR (Table 1). The flow rate at $\mathrm{S} 5$ right after confluence with Kim Nguu River was $6.68 \mathrm{~m}^{3} / \mathrm{s}$, nearly doubled that $\left(3.53 \mathrm{~m}^{3} / \mathrm{s}\right)$ at S4 located after confluence with Lu River. The same pattern was found between S3 and S4. Those indicated the high water flow rate from both $\mathrm{Lu}$ and Kim Nguu to TLR.

Since velocity increases toward downstream, travel time of water decreases which takes 0.43 day $/ \mathrm{km}$ between S1-S2, 0.26, 0.14 and 0.09 day $/ \mathrm{km}$ between S2-S3, $\mathrm{S} 3-\mathrm{S} 4$ and S4-S5 river reaches, respectively. As a con- sequence, sediment also become shallower toward downstream; $1.2 \mathrm{~m}$ depth at $\mathrm{S} 1, \mathrm{~S} 2$ and $\mathrm{S} 3,0.9 \mathrm{~m}$ at $\mathrm{S} 4$, and only $0.6 \mathrm{~m}$ at S5 (Table 1). Based on cross-sectional area of sediment body and length of each river reach, total sediment accumulated in river bed was estimated. Lowest amount of sediment of $34,161 \mathrm{~m}^{3}$ was observed at reach between S1-S2, then 42,395 between S4-S5, 89,139 between $\mathrm{S} 2-\mathrm{S} 3$, and the highest of $117,888 \mathrm{~m}^{3}$ between S3-S4. Meanwhile, sediment density increases gradually to downstream (Table 1).

\subsection{Sediment Quality}

High variation of total organic carbon (TOC) and heavy metal concentrations among sampling sites was found (Table 2). TOC content varied between 11 at $\mathrm{S} 4$ and 60 $\mathrm{g} / \mathrm{kg}$ at S3. Meanwhile, Cr ranged from 90 at S4 to 229 $\mathrm{mg} / \mathrm{kg}$ at $\mathrm{S} 2 ; \mathrm{Mn}$ ranged from 392 at $\mathrm{S} 1$ to 610 at $\mathrm{S} 2 ; \mathrm{Fe}$ ranged from 13,139 at $\mathrm{S} 1$ to 22,442 at $\mathrm{S} 4$; $\mathrm{Ni}$ ranged from 51 at $\mathrm{S} 2$ to 98 at $\mathrm{S} 3$; $\mathrm{Cu}$ ranged from 57 at $\mathrm{S} 4$ to 146 at $\mathrm{S} 2 ; \mathrm{Zn}$ ranged from 255 at S4 to 783 at S3; As ranged from 16 at $\mathrm{S} 4$ to 28 at $\mathrm{S} 3 ; \mathrm{Cd}$ ranged from 1.0 at $\mathrm{S} 1$ to 35 at $\mathrm{S} 3$; and $\mathrm{Pb}$ ranged from 58 at $\mathrm{S} 4$ to $92 \mathrm{mg} / \mathrm{kg}$ at S3. Comparing among heavy metals, the average concentrations in sediment increased following the order of $\mathrm{Cd}<\mathrm{As}<\mathrm{Ni}<\mathrm{Pb}<\mathrm{Cu}<\mathrm{Cr}<\mathrm{Mn}<\mathrm{Zn}<\mathrm{Fe}$ (Table 2).

Table 2. Mean ${ }^{1}$ concentration $( \pm \mathrm{SD})$ of total organic carbon $(\mathrm{TOC} ; \mathrm{g} / \mathrm{kg})$ and heavy metals $(\mathrm{mg} / \mathrm{kg})$ in sediment at specific sampling sites along To Lich River.

\begin{tabular}{|c|c|c|c|c|c|c|c|c|c|c|}
\hline Sampling site & TOC & $\mathrm{Cr}$ & $\mathrm{Mn}$ & $\mathrm{Fe}$ & $\mathrm{Ni}$ & $\mathrm{Cu}$ & $\mathrm{Zn}$ & As & $\mathrm{Cd}$ & $\mathrm{Pb}$ \\
\hline S1 & $48.3 \pm 7.1$ & $229.0 \pm 75.3$ & $\begin{array}{c}392.0 \\
\pm 57.6\end{array}$ & $\begin{array}{r}13139.5 \\
\pm 3142.7\end{array}$ & $51.4 \pm 6.7$ & $103.6 \pm 18.0$ & $\begin{array}{l}513.4 \\
\pm 73.4\end{array}$ & $21.6 \pm 4.2$ & $1.0 \pm 0.2$ & $75.9 \pm 15.7$ \\
\hline S2 & $33.5 \pm 3.0$ & $144.7 \pm 36.1$ & $\begin{array}{r}610.9 \\
\pm 92.4\end{array}$ & $\begin{array}{c}21718.3 \\
\pm 4820.2\end{array}$ & $77.4 \pm 12.1$ & $146.8 \pm 12.0$ & $\begin{array}{l}770.6 \\
\pm 82.6\end{array}$ & $24.7 \pm 3.9$ & $2.3 \pm 0.3$ & $90.4 \pm 10.0$ \\
\hline S3 & $60.8 \pm 15.3$ & $128.4 \pm 36.3$ & $\begin{array}{c}438.5 \\
\pm 121.9\end{array}$ & $\begin{array}{c}16783.3 \\
\pm 5308.0\end{array}$ & $98.4 \pm 17.5$ & $139.7 \pm 50.6$ & $\begin{array}{c}783.1 \\
\pm 301.8\end{array}$ & $28.9 \pm 13.5$ & $35.3 \pm 47.0$ & $92.3 \pm 27.1$ \\
\hline S4 & $11.7 \pm 7.6$ & $90.1 \pm 24.4$ & $\begin{array}{r}572.0 \\
\pm 53.5\end{array}$ & $\begin{array}{c}22442.8 \\
\pm 2373.4\end{array}$ & $68.7 \pm 21.7$ & $57.8 \pm 21.8$ & $\begin{array}{c}255.2 \\
\pm 137.5\end{array}$ & $16.7 \pm 4.0$ & $4.0 \pm 4.9$ & $58.7 \pm 14.2$ \\
\hline S5 & $19.5 \pm 3.5$ & $132.7 \pm 34.6$ & $\begin{array}{l}538.8 \\
\pm 50.4\end{array}$ & $\begin{array}{l}21585.3 \\
\pm 384.5\end{array}$ & $70.2 \pm 10.3$ & $74.1 \pm 11.0$ & $\begin{array}{l}412.5 \\
\pm 78.6\end{array}$ & $23.7 \pm 4.5$ & $13.2 \pm 1.9$ & $63.0 \pm 8.0$ \\
\hline Mean & $34.7 \pm 20.2$ & $145.0 \pm 51.2$ & $\begin{array}{l}510.4 \\
\pm 92.0\end{array}$ & $\begin{array}{c}19133.8 \\
\pm 4034.1\end{array}$ & $73.2 \pm 17.0$ & $104.4 \pm 39.2$ & $\begin{array}{c}547.0 \\
\pm 229.2\end{array}$ & $23.1 \pm 4.5$ & $11.2 \pm 14.3$ & $76.1 \pm 15.3$ \\
\hline Sampling in $2005^{2}$ & - & 570.2 & - & - & 74.0 & 333.2 & 390.8 & - & 9.6 & 375.3 \\
\hline Sampling in $1997^{3}$ & - & 580.1 & - & - & 14.9 & 158.7 & 192.7 & 35.2 & - & 139.0 \\
\hline $\begin{array}{c}\text { QCVN } \\
\text { 03: 2008/BTNMT } \\
\text { for agricultural soil }\end{array}$ & - & - & - & - & - & 50 & 200 & 12 & 2 & 70 \\
\hline $\begin{array}{c}\text { QCVN } \\
\text { 03: 2008/BTNMT } \\
\text { for industrial soil }\end{array}$ & - & - & - & - & - & 100 & 300 & 12 & 10 & 300 \\
\hline $\mathrm{MCC}^{4}$ & - & 400 & - & - & 110 & 200 & 450 & - & 3 & 300 \\
\hline
\end{tabular}

${ }^{1}$ mean of all sediment layers in each sampling site for TOC and specific heavy metal; ${ }^{2}$ cited from Nguyen et al. [25]; ${ }^{3}$ cited from HSDC (1997), QCVN 03: 2008/BTNMT-Vietnamese technical regulation on the allowable limits of heavy metals in soils; ${ }^{4}$ maximum permissible concentrations of potentially toxic heavy metal for crops after application of sewage sludge [26]. 
Concentrations of $\mathrm{Zn}$ and $\mathrm{Cd}$ far exceeded the maximum permissible concentrations of potentially toxic heavy metal for crops after application of sewage sludge [26]. Comparing to Vietnamese standard, contents of most concerned heavy metals exceeded the allowable limit for both agricultural and industrial soils (Table 2).

There were huge amounts of TOC and heavy metal accumulated in sediment in specific river reaches (Table 3). The highest amount belonged to TOC with a total of 12,745 tons in whole river sediment, followed by $\mathrm{Fe}$ of $6815, \mathrm{Zn}$ of 201, Mn of $179, \mathrm{Cr}$ of $43, \mathrm{Cu}$ of $38, \mathrm{~Pb}$ and Ni of 27 tons each, As of 8 , and Cd of 5.4 tons.

\subsection{Water Quality}

There was not much variation in $\mathrm{pH}$, ranging around 7.2 - 7.3 among sampling sites. Meanwhile, high variation was observed for total organic carbon (TOC; Table 4), the highest value found in $\mathrm{S} 2$ of $8.3 \mathrm{mg} / \mathrm{L}$ nearly doubled that in $\mathrm{S} 1(4.7 \mathrm{mg} / \mathrm{L})$. Concentrations of $\mathrm{Cr}, \mathrm{Ni}, \mathrm{Cu}$, and $\mathrm{Pb}$ were lower than $10 \mu \mathrm{g} / \mathrm{L}$ and not much different among all sampling sites. Meanwhile, that of $\mathrm{Zn}$, As, and Mn were much higher, ranging from 36 to $60,13-76$, and $83-400 \mu \mathrm{g} / \mathrm{L}$, respectively. Except $\mathrm{Mn}$, all other heavy metals were still under recommended levels for irrigation water (Table 4).

Using heavy metal and organic carbon concentrations of sampling sites to apply mass balance model (Equation (4)), total loads of TOC and heavy metal generated to each river reach and at the end of To Lich River (TLR) before discharging to Nhue River were estimated (Table 5). High variation of loads of TOC and heavy metal was found among river reaches; ranging from 338 to $2,036 \mathrm{~kg}$ /day

Table 3. Total load of total organic carbon (TOC) and heavy metal in sediment in specific reaches of To Lich River.

\begin{tabular}{cccccccccccc}
\hline River reach & Unit & TOC & $\mathrm{Cr}$ & $\mathrm{Mn}$ & $\mathrm{Fe}$ & $\mathrm{Ni}$ & $\mathrm{Cu}$ & $\mathrm{Zn}$ & $\mathrm{As}$ & $\mathrm{Cd}$ & $\mathrm{Pb}$ \\
\hline \multirow{2}{*}{$\mathrm{S} 1$-S2 } & total (ton) & 1470.3 & 6.7 & 18.0 & 626.9 & 2.3 & 4.5 & 23.1 & 0.8 & 0.1 & 3.0 \\
& $\mathrm{~kg} / \mathrm{m}^{3}$ & 43.041 & 0.197 & 0.528 & 18.353 & 0.068 & 0.132 & 0.676 & 0.024 & 0.002 & 0.088 \\
& total (ton) & 5019.8 & 14.5 & 55.9 & 2050.6 & 9.4 & 15.3 & 82.8 & 2.9 & 2.0 & 9.7 \\
$\mathrm{~S} 2-\mathrm{S} 3$ & $\mathrm{~kg} / \mathrm{m}^{3}$ & 56.314 & 0.163 & 0.627 & 23.005 & 0.105 & 0.171 & 0.928 & 0.032 & 0.022 & 0.109 \\
& total (ton) & 5301.5 & 16.0 & 74.0 & 2871.7 & 12.2 & 14.5 & 76.0 & 3.3 & 2.9 & 11.0 \\
$\mathrm{~S} 3-\mathrm{S} 4$ & $\mathrm{~kg} / \mathrm{m}^{3}$ & 44.971 & 0.136 & 0.628 & 24.359 & 0.104 & 0.123 & 0.645 & 0.028 & 0.024 & 0.094 \\
& total (ton) & 896.5 & 6.4 & 32.0 & 1266.5 & 4.0 & 3.8 & 19.2 & 1.2 & 0.5 & 3.5 \\
S4-S5 & $\mathrm{kg} / \mathrm{m}^{3}$ & 21.147 & 0.151 & 0.754 & 29.873 & 0.094 & 0.089 & 0.453 & 0.027 & 0.012 & 0.083 \\
\multirow{2}{*}{ Grand total } & ton & 12688.2 & 43.7 & 179.9 & 6815.7 & 27.9 & 38.0 & 201.1 & 8.2 & 5.4 & 27.3 \\
\hline
\end{tabular}

Concentration of TOC and heavy metal as mean of all layers (Table 2) at first and last points of specific river reach was used for calculation. Load of TOC and heavy metal equals to mean concentration multiplying total sediment amount corresponding to its density in a specific river reach (Table 1).

Table 4. pH value, concentration of total organic carbon (TOC; mg/L) and heavy metals $(\mu \mathrm{g} / \mathrm{L})$ in water at specific sampling sites in To Lich River.

\begin{tabular}{ccccccccccc}
\hline Sampling site & $\mathrm{pH}$ & $\mathrm{TOC}$ & $\mathrm{Cr}$ & $\mathrm{Mn}$ & $\mathrm{Ni}$ & $\mathrm{Cu}$ & $\mathrm{Zn}$ & $\mathrm{As}$ & $\mathrm{Cd}$ & $\mathrm{Pb}$ \\
\hline $\mathrm{S} 1$ & 7.2 & 4.7 & 2 & 83.7 & 5 & 5 & 58 & 47.3 & $<0.2$ & 8 \\
$\mathrm{~S} 2$ & 7.3 & 8.3 & 2 & 400.8 & 5 & 4 & 40 & 76.2 & $<0.2$ & 7 \\
$\mathrm{~S} 3$ & 7.2 & 7.7 & 2 & 230.7 & 8 & 3 & 36 & 13.1 & $<0.2$ & 6 \\
$\mathrm{~S} 4$ & 7.3 & 8.1 & 5 & 188.7 & 9 & 7 & 60 & 38.2 & $<0.2$ & 8 \\
$\mathrm{~S} 5$ & 7.2 & 7.8 & 2 & 200.9 & 7 & 4 & 28 & 28.1 & $<0.2$ & 10
\end{tabular}

\begin{tabular}{ccccccccccc} 
Mean $\pm \mathrm{SD}$ & $7.24 \pm 0.05$ & $7.32 \pm 1.48$ & $2.60 \pm 1.34$ & $220.96 \pm 114.80$ & $6.80 \pm 1.79$ & $4.60 \pm 1.52$ & $44.40 \pm 14.03$ & $40.58 \pm 23.61$ & $-7.80 \pm 1.48$ \\
Sampling in $2005^{1}$ & 7.3 & 21.2 & 8.4 & 114.0 & 6.0 & 4.6 & 31.6 & 5.6 & - & 1.9 \\
Sampling in $1997^{2}$ & - & - & 13 & 220 & 4 & 20 & 2000 & 66 & - & 160 \\
CVN 5942-1995 B & $5.5-9$ & - & 1000 & 800 & 1000 & 1000 & 2000 & 100 & 20 & 100 \\
$\begin{array}{l}\text { Irrigation water } \\
\text { guidelines }^{4}\end{array}$ & $6.5-8$ & - & 100 & 200 & 200 & 200 & 2000 & 100 & 10 & 5000 \\
Freshwater $^{5}$ & - & - & 1.0 & 8.0 & 0.5 & 3.0 & 15.0 & 0.5 & - & 3.0 \\
\hline
\end{tabular}

${ }^{1}$ cited from Kikuchi et al. [27]; ${ }^{2}$ cited from HSDC [28]; ${ }^{3}$ surface water quality standard in Vietnam used for the purpose other than domestic water supply including irrigation water; ${ }^{4} \mathrm{WHO}[29] ;{ }^{5}$ median values of freshwater in the world [30]. 
To Lich River Inner City Hanoi, with Special Reference to Heavy Metals

Table 5. Total heavy metal and organic carbon (TOC) discharged to specific reaches of To Lich River (kg/day).

\begin{tabular}{|c|c|c|c|c|c|}
\hline & \multirow{2}{*}{${ }^{1}$ Attenuation rate- } & \multicolumn{4}{|c|}{ River reach } \\
\hline & & $\mathrm{S} 1-\mathrm{S} 2$ & $\mathrm{~S} 2-\mathrm{S} 3$ & S3-S4 & S4-S5 \\
\hline TOC & 0 & 338 & 360 & 1697 & 2036 \\
\hline $\mathrm{Cr}$ & 0.19 & 0.07 & 0.12 & 1.35 & - \\
\hline $\mathrm{Mn}$ & 0 & 18.55 & 3.25 & 34.40 & 58.51 \\
\hline $\mathrm{Ni}$ & 0.21 & 0.18 & 0.60 & 2.04 & 1.40 \\
\hline $\mathrm{Cu}$ & 0.25 & 0.14 & 0.15 & 1.88 & 0.27 \\
\hline $\mathrm{Zn}$ & 0.24 & 1.25 & 2.07 & 15.19 & - \\
\hline As & 0.21 & 3.16 & - & 10.49 & 5.01 \\
\hline $\mathrm{Pb}$ & 0.19 & 0.24 & 0.32 & 1.91 & 3.42 \\
\hline
\end{tabular}

${ }^{1}$ cited from Ambrose et al. [31], there are no attenuation rates for TOC and $\mathrm{Mn}$ available, the value of zero was used for estimation. Estimated values of $\mathrm{Cr}$ and $\mathrm{Zn}$ in S4-S5 river reach and of As in S2-S3 river reach were negative, they were excluded.

for TOC, 0.07 - 1.35 for $\mathrm{Cr}, 3.25$ - 58.51 for $\mathrm{Mn}, 0.18$ 2.04 for $\mathrm{Ni}, 0.14-1.88$ for $\mathrm{Cu}, 1.25$ - 15.19 for $\mathrm{Zn}, 3.16$ 10.49 for As, and from 0.24 to $3.42 \mathrm{~kg}$ /day for $\mathrm{Pb}$. In general, river reaches of S1-S2 and S2-S3 in upstream, where received mostly domestic wastewater, had lower loads of all heavy metals and TOC compared to that of S3-S4 and S4-S5 river reaches in downstream (Table 5), which received various types of wastewater. TOC discharged from TLR to Nhue River reached 4,504 kg/day (Table 6), while that of heavy metals was much lower; $1.15 \mathrm{~kg}$ /day for $\mathrm{Cr}, 2.31$ for $\mathrm{Cu}, 4.04$ for $\mathrm{Ni}, 5.77$ for $\mathrm{Pb}$, 16.17 for $\mathrm{Zn}, 16.22$ for As, and up to $116 \mathrm{~kg}$ /day for $\mathrm{Mn}$.

Based on estimated data of population, water supply per capital, and water use in industry in TLR system basin, discharge of TOC and heavy metals from To Lich to Nhue rivers was estimated (Table 6). Wastewaters volume increased year by year, from $450,922 \mathrm{~m}^{3} /$ day in 2005 to $577,399 \mathrm{~m}^{3} /$ day in 2011 and may up to 718,750 $\mathrm{m}^{3} /$ day in 2020 . This was accompanied by the increase in heavy metals loaded to Nhue River; Mn of $51.41 \mathrm{~kg} /$ day in 2005 to 116 in 2011 and to $144.4 \mathrm{~kg} /$ day in 2020 , As of $2.53 \mathrm{~kg}$ /day in 2005 to 16.22 in 2011 and to 20.20 $\mathrm{kg} /$ day in 2020, and other heavy metals (Table 6).

\subsection{River Quality}

Table 7 shows values of water and sediment quality indices of To Lich River (TLR). The embankment of TLR started in 1998 and finished in 2002. To understand the efficiency of embankment on river quality, concentrations of heavy metal in water and sediment in 1997 and in 2005 were used to compare with that in the present study. Water quality was much improved in 2005 and in 2011 compared to pre-embankment as water quality in- dex of pair of 2005-1997 was 0.43 and that of 2011-1997 was 0.55 . However, quality of water in 2011 became worse than that in 2005. Conversely, sediment quality became worse after embankment indicated by index of 2.55 between 2005-1997 and of 1.84 between 2011-1997. Sediment quality in 2011 was much improved compared to that in 2005, representing by index of 0.63 . Combining water and sediment quality indices indicated that river quality was not improved; it even became more polluted as values of river quality index were higher than 1 for all pairs of year comparison (Table 7).

\section{Discussion}

It is clear that water of To Lich River (TLR) should be treated prior to use on crops as the Mn concentration exceeded recommended level for irrigation (Table 4). Since wastewaters discharged to river reaches between S1 and S3 were mostly of domestic origin, total load of total organic carbon (TOC) and heavy metal were much lower than that in downstream reaches between $\mathrm{S} 3$ and S5 (Table 5). This may suggest the responsibility of industry for heavy metal discharges rather than of domestic practices. Higher loads of $\mathrm{Cr}, \mathrm{Ni}, \mathrm{Cu}, \mathrm{Zn}$, and $\mathrm{As}$ in river reach between $\mathrm{S} 3-\mathrm{S} 4$ compared to that between $\mathrm{S} 4-\mathrm{S} 5$ (Table 5) indicated that industry within catchment of $\mathrm{Lu}$ River, which joints TLR before sampling site S4, may generate higher amount of those metals compared to that in Kim Nguu River catchment (Figure 1). Load of $\mathrm{Cr}$ and $\mathrm{Zn}$ in $\mathrm{S} 4-\mathrm{S} 5$ and of $\mathrm{As}$ in $\mathrm{S} 2-\mathrm{S} 3$ river reaches were negative (Table 5), which must be always $\geq$ zero. This may be due to the attenuation rates of this study site are not available, then they were cited from Ambrose et al. [31], who indicated dissolved and absorbed capacity of heavy metal as a function of suspended solid concentrations in streams around the world. It may suggests that attenuation rate of heavy metals in TLR should be higher as result of low velocity, higher concentration in water, and others.

Taking into account of TOC, which nearly upped to 4.5 tons/day (Table 6) discharged to Nhue River and of nutrient contents in water [32], if wastewater is treated properly and reused in agriculture, it may sustain water supply, reduce input costs, and increase crop's productivity and farm income [33]. An integrated cost-benefit analysis of wastewater reuse should be conducted, after implementation of an adequate wastewater treatment system for TLR basin, which is now under consideration. Currently, agricultural products irrigated using TLR water have been ostracized by consumers because of water contamination.

Sediment of TLR cannot be directly used for any purposes neither agriculture [26] nor industry (QCVN 03: 2008/BTNMT; Table 2). It must be treated following 
Table 6. Total load ${ }^{1}$ of total organic carbon (TOC) and heavy metal at the end of To Lich River before discharging to Nhue River by year (kg/day).

\begin{tabular}{cccccccccc}
\hline Year & TOC & $\mathrm{Cr}$ & $\mathrm{Mn}$ & $\mathrm{Ni}$ & $\mathrm{Cu}$ & $\mathrm{Zn}$ & $\mathrm{As}$ & $\mathrm{Pb}$ & ${ }^{2}$ Water discharge $\left(\mathrm{m}^{3} / \mathrm{day}\right)$ \\
\hline $2005^{3}$ & 9560 & 3.79 & 51.41 & 2.71 & 2.07 & 14.25 & 2.53 & 0.86 & 450,922 \\
$2011^{4}$ & 4504 & 1.15 & 116.00 & 4.04 & 2.31 & 16.17 & 16.22 & 5.77 & 577,399 \\
$2020^{5}$ & 5606 & 1.44 & 144.40 & 5.03 & 2.88 & 20.13 & 20.20 & 7.19 & 718,750 \\
\hline
\end{tabular}

${ }^{1}$ equals to $\mathrm{Q}_{\mathrm{d}} \times \mathrm{C}_{\mathrm{d}}\left(\mathrm{Q}_{\mathrm{d}}\right.$ and $\mathrm{C}_{\mathrm{d}}$ are downstream discharge and concentration, respectively); ${ }^{2}$ at the end of To Lich River; ${ }^{3}$ discharge data is citied from Nguyen [15], while TOC and heavy metal concentrations are cited from Kikuchi et al. [27]; ${ }^{4}$ from this study; ${ }^{5}$ assuming that TOC and heavy metal concentrations are the same as in this study, while discharge is based on the data of population change and change of freshwater supply per capital in TLR system basin [15].

Table 7. Water, sediment, and river quality indices of To Lich River.

\begin{tabular}{cccc}
\hline $\begin{array}{c}\text { Pair of } \\
\text { comparison (year-year) }\end{array}$ & $\begin{array}{c}\text { Water quality } \\
\text { index }\end{array}$ & $\begin{array}{c}\text { Sediment } \\
\text { quality index }\end{array}$ & $\begin{array}{c}\text { River quality } \\
\text { index }\end{array}$ \\
\hline $2011^{1}-2005^{2}$ & 2.45 & 0.63 & 1.54 \\
$2005-1997$ & 0.43 & 2.55 & 1.49 \\
$2011-1997^{3}$ & 0.55 & 1.84 & 1.19 \\
\hline
\end{tabular}

Heavy metal concentration data ${ }^{1}$ from this study; ${ }^{2}$ cited from Kikuchi et al. [27]; and ${ }^{3}$ cited from HSDC [28].

suitable guidelines for specific purpose, even treatment and reuse of heavily contaminated dredged sediments is not a cost-effective alternative to confined disposal [34], which becomes secondary source of contamination. Treatment technologies and experiences have never been put into consideration for sediment of TLR system in Hanoi, or even in the world for heavy metal contaminated sediment in general [35]. This may be the barriers for environmental improvement of TLR. There was a total of $284,000 \mathrm{~m}^{3}$ of sediment in TLR (Table 1), which contained high concentration of heavy metals (Table 2). Depending on required quality of sediment after treatment, the technologies [36] may be different leading to differences in treatment cost, ranging from 36 to 600 $\mathrm{USD} / \mathrm{m}^{3}$ based on composite unit cost estimation in USA [18]. Total cost estimated for treating sediment in TLR ranges from 10.2 to 170 million USD, which excludes costs for dredging, transportation, monitoring, and management of residuals. One again, after treated if it is used for agriculture much benefit will come to farmers because of high nutrient and organic carbon content in sediment. Embankment of TLR finished in 2002 [15], if equalizing sedimentation deposit annually there was $30,000 \mathrm{~m}^{3}$ of sediment accumulated in TLR bed, it may require annual cost of 1.2 - 19 million USD for sediment treatment.

Accumulation of $\mathrm{Fe}, \mathrm{Mn}, \mathrm{Ni}, \mathrm{Pb}, \mathrm{As}$, and $\mathrm{Cd}$ in sediment was lowest in river reach between S1 and S2 (Table 3), where discharge was mostly from domestic origin (Figure 1). Meanwhile, levels of $\mathrm{Cr}, \mathrm{Cu}, \mathrm{Zn}$, and TOC was lowest in downstream river reach between S4 and S5, this may result from higher flow rate of nearly 10 times of downstream compared to upstream (Table 1). The highest accumulations of $\mathrm{Mn}$ and As were also found in downstream river reach (S4-S5; Table 3), even their concentrations in water were not higher than other river reaches (Table 4). This is explained by the higher density of sediment of S4-S5 river reach compared to others in upstream (Table 1) and/or those metals prefer to bind with heavier suspended particles. In general, sediment density increases toward downstream as a result of higher flow rate, which may bring higher amount of lightly suspended particles. In addition, sediment in further downstream becomes more compact which restricts re-suspended process to release heavy metals to water.

Discharge of heavy metals and TOC to Nhue River at the end of TLR in 2011 (Table 6) may be underestimate since it was based on water discharge of only 2 investigated days of March 4 and 5 in dry season in 2011, when there was no rain. The fact is that dirty on land surface of TLR system basin may contain much organic carbon and heavy metals as result of transportation, municipal and industrial solid waste disposals, which all will be discharged to TLR on rainy days. The same case for projected data in 2020 , since concentration of heavy metals and TOC in water are predicted to be the same values in 2011 and uncertainty of population in 2020. Currently, there is no clear plan on building wastewater treatment plants for whole TLR system basin, which may lead to more serious water pollution in near future.

Water quality index (WQI) showed that quality of water was much improved after embankment (Table 7) as result of reducing stagnation due to improving flow rate. Because of no suitable wastewater treatment, river management strategy and/or elevated discharge of heavy metals to wastewaters from urbanization, water quality has been becoming worse indicated by increase of WQI to 2.45 between 2011 and 2005 (Table 7). Conversely, it was observed for quality of sediment. Sediment became more polluted after embankment, indicated by sediment quality index (SQI) of 2.55 and 1.84 for pairs of 2005- 
1997 and 2011-1997, respectively. The fact is that sediment was almost removed from river bed as preparation for embankment activities, the new layers of sediment were accumulated afterward. Since 2002 after completing embankment, population growth, rapid urbanization, and speed-up of manufacturing activities of industrial zones within TLR system basin led to increaseing the amount and pollution level of discharges, which contained high amount of suspended particles for sedimentation process [15]. However comparing between 2005 and 2011 , sediment quality was improved (SQI $=0.63$ ). Probably, pre-physical wastewater treatment was paid much attention by industrial zones to remove as much big particles as possible before discharging as result of issuing environmental regulations recently. The health of a river should be considered in terms of both water and sediment bodies, hence river quality index (RQI) was derived from WQI and SQI (Table 7). Quality of TLR has not yet improved since embankment, it even became worse. To improve quality of a river, wastewater should be treated properly before discharging to its body. Meanwhile, the main purpose of TLR embankment was improving water flow rate and reducing solid waste disposal on river banks.

\section{Conclusions}

This study indicated that concentration of only $\mathrm{Mn}$ in water of To Lich River (TLR) inner Hanoi City, Vietnam exceeds irrigation standard, meanwhile concentrations of $\mathrm{Cu}, \mathrm{Zn}, \mathrm{As}$, and $\mathrm{Cd}$ in sediment exceed Vietnamese standard for both agricultural and industrial soils.

There is an amount of nearly $300,000 \mathrm{~m}^{3}$ sediments accumulated in TLR since finishing embankment in 2002, which may cost up to 170 million USD for treatment. Even though, the technologies and experiences are still limited in study site.

After almost ten years of embankment, quality of TLR was not improved; it even became more contaminated in terms of heavy metals in both sediment and water. To improve the environmental quality of a river, embankment is not enough and just an initial stage. In the next step, wastewater should be fully treated at sources before discharging to TLR and if possible annual sediment dredging should also be implemented. This not only increases water flow rate, but also reduces re-suspended process of heavy metals from sediment.

\section{Acknowledgements}

Comments from the anonymous reviewers are gratefully acknowledged. This study was financially supported by Kyoto University, Global COE Program.

\section{REFERENCES}

[1] M. Schiff and L. A. Winters, "Regional Cooperation, and the Role of International Organizations and Regional Integration," Policy Research Working Paper, World Bank, Washington DC, 2002.

[2] R. Saracci and P. Vineis, "Disease Proportions Attributable to Environment," Environmental Health, Vol. 6, 2007, p. 38. doi:10.1186/1476-069X-6-38

[3] A. Pruss-Ustun and C. Corvalan, "How Much Disease Burden Can Be Prevented by Environmental Interventions?" Epidemiology, Vol. 18, No. 1, 2007, pp. 167-178. doi:10.1097/01.ede.0000239647.26389.80

[4] A. Pruss-Ustun and C. Corvalan, "Preventing Disease through Healthy Environments. Towards an Estimate of the Environmental Burden of Disease," World Health Organization, Geneva, 2006.

[5] K. J. Rothman and S. Greenland, "Modern Epidemiology," Lippincott Williams and Wilkins, Philadelphia, 1998.

[6] M. Susser, "What Is a Cause and How Do We Know One? A Grammar for Pragmatic Epidemiology," American Journal of Epidemiology, Vol. 133, No. 7, 1991, pp. 635-648.

[7] T. Schueler, "A Practical Manual for Planning and Designing Urban BMPs," Metropolitan Council of Governments, Washington DC, 1987.

[8] K. J. Crawford and D. R. Lenat, "Effects of Land Use on Tile Water Quality and Biota of Three Streams in The Piedmont Province of North Carolina," US Geological Survey, Water Resources Investigations Report 89-4007, Raleigh, 1989.

[9] C. F. Mason, "Biology of Freshwater Pollution," Longman Group Ltd., New York, 1981.

[10] H. P. Guy, "Urban Sedimentation in Perspective," Proceeding of the American Society of Civil Engineers, Journal of the Hydraulics Division December, Vol. 98, 1972, pp. 2099-2116.

[11] O. S. Owen, "Natural Resource Conservation," MacMillan, New York, 1975.

[12] C. E. Simmons, "Sediment Characteristics of North Carolina Streams," USGS Open-File Report 870-701, Raleigh, 1987.

[13] V. Novotny and G. Chesters, "Delivery of Sediment and Pollutants from Nonpoint Sources: A Water Quality Perspective," Journal of Soil and Water Conservation, Vol. 44, No. 6, 1989, pp. 568-576. doi:10.2489/jswc.64.3.173

[14] G. Bortone, E. Arevalo, I. Deibel, H. D. Detzner, L. de Propris, F. Elskens, A. Giordano, P. Hakstege, K. Hamer, J. Harmsen, A. Hauge, L. Palumbo and J. van Veen, "Sediment and Dredged Material Treatment," Journal of Soils and Sediments, Vol. 4, No. 4, 2004, pp. 225-232. doi:10.1007/BF02991117

[15] V. C. Nguyen, "Establishing Scientific Basics for Surface Water Supplement Solution to Improve River Water Quality in Hanoi City," Hanoi Department of Science and Technology, Hanoi, 2005.

[16] Hanoi DONRE, "Feasible Project on Establishing Large- 
Scale Wastewater Treatment Plants to Improve Environment in Hanoi," Hanoi Department of Natural Resources and Environment, Hanoi, 2009.

[17] USEPA, "Method 3051A: Microwave Assisted Acid Dissolution of Sediments, Sludges, Soils, and Oils," Revision 1, United States Environmental Protection Agency, Washington DC, 2007.

[18] T. E. Myers, "Cost Estimating for Contaminated Sediment Treatment-A Summary of the State of the Practice, DOER Technical Notes Collection (ERDC TN-DOERR8)," US Army Engineer Research and Development Center, Vicksburg, 2005.

http://el.erdc.usace.army.mil/dots/doer/

[19] D. M. Dolan and A. H. Shaarawi, "Inferences about Point Source Loadings from Upstream/Downstream River Monitoring Data," Environmental Monitoring and Assessment, Vol. 12, No. 2-3, 1996, pp. 343-357. doi:10.1007/BF00394239

[20] R. Jha, C. S. P Ojha and K. K. S. Bhatia, "Non-Point Source Pollution Estimation Using a Modified Approach," Hydrological Process, Vol. 21, No. 8, 2007, pp. 10981105. doi:10.1002/hyp.6291

[21] S. M. Liou, S. L. Lo and S. H. Wang, "A Generalized Water Quality Index for Taiwan," Environmental Monitoring and Assessment, Vol. 96, No. 1-3, 2004, pp. 35-52. doi:10.1023/B:EMAS.0000031715.83752.a1

[22] A. Parparov, K. D. Hambright, L. Hakanson and A. Ostapenia, "Water Quality Quantification: Bbasics and Implementation," Hydrobiologia, Vol. 560, No. 1, 2006, pp. 227237. doi:10.1007/s10750-005-1642-y

[23] A. A. Bordalo, R. Teixeira and W. J. Wiebe, "A Water Quality Index Applied to an International Shared River Basin: The Case of the Douro River," Environmental Management, Vol. 38, No. 6, 2006, pp. 910-920. doi:10.1007/s00267-004-0037-6

[24] T. Banerjee and R. K. Srivastava, "Application of Water quality Index for Assessment of Surface Water Quality Surrounding Integrated Industrial Estate-Pantnagar," Water Science and Technology, Vol. 60, No. 8, 2009, pp. 2041-2053. doi:10.2166/wst.2009.537

[25] T. L. H. Nguyen, M. Ohtsubo, L. Li, T. Higashi and M. Kanayama, "Heavy Metal Characterization and Leachability of Organic Matter-rich River Sediments in Hanoi, Vietnam," International Journal of Soil, Sediment and Water, Vol. 3, No. 1, 2010, pp. 1940-3259.

[26] P. M. Steve, "Effect of Heavy Metals from Sewage
Sludge on Soil Microbes in Agricultural Ecosystems," In: S. M. Ross, Ed., Toxic Metals in Soil-Plant System, John Wiley and Sons, Chichester, 1994, pp. 247-275.

[27] T. Kikuchi, T. Furuichi, H. T. Hai and S. Tanaka, "Assessment of Heavy Metal Pollution in River Water of Hanoi, Vietnam Using Multivariate Analyses," Bulletin of Environmental Contamination and Toxicology, Vol. 83, No. 3, 2009, pp. 575-582. doi:10.1007/s00128-009-9815-4

[28] HSDC, "Report on Improving Environmental of To Lich River (Stage I)," Hanoi Sewerage and Drainage Limited Company, Hanoi, 1997.

[29] WHO, "Guidelines for the Safe Use of Wastewater, Excreta and Greywater," Volume II: Wastewater Use in Agriculture, 2006.

[30] H. J. M. Bowen, "Environmental Chemistry of the Elements," Academic Press, London, 1979.

[31] R. B. Ambrose, T. Wool, J. L. Martin, J. P. Collolly and R. W. Schanz, "WASP5X: A Hydrodynamic and Water Quality Model-Model Theory, User's Manual and Programmer's Guide," US Environmental Protection Agency, Athens, 1991.

[32] A. D. Trinh, "Study of Water Quality of a Urban River hydro System in the Periphery of Hanoi (Vietnam); Experiment and Modeling," $\mathrm{PhD}$. Dissertation, University of Joseph Fourier, Grenoble, 2003.

[33] F. Rijsberman, "Sanitation and Access to Clean Water," In: B. Lomborg, Ed., Global Crises, Global Solutions, Cambridge University Press, London, 2004, pp. 363-420. doi:10.1017/CBO9780511492624.010

[34] V. Bert, P. Seuntjens, W. Dejonghe, S. Lacherez, H. T. T. Thuy and B. Vandecasteele, "Phytoremediation as a Management Option for Contaminated Sediments in Tidal Marshes, Flood Control Areas and Dredged Sediment Landfill Sites," Environmental Science Pollution Research, Vol. 16, No. 7, 2009, pp. 745-764. doi:10.1007/s11356-009-0205-6

[35] J. F. Peng, Y. H. Song, P. Yuan, X. Y. Cui and G. L. Qiu, "The Remediation of Heavy Metals Contaminated Sediment," Journal of Hazardous Materials, Vol. 161, No. 2-3, 2009, pp. 633-640. doi:10.1016/i.jhazmat.2008.04061

[36] U. Foerstner and S. Apitz, "Sediment Remediation: US Focus on Capping and Monitored Natural Recovery," Journal of Soils and Sediments, Vol. 7, No. 6, 2007, pp. 351358. doi:10.1065/iss2007.10.256 